\title{
PEMBERDAYAAN MASYARAKAT DI DAERAH TUJUAN WISATA DESA PEMUTERAN DALAM RANGKA PENGEMBANGAN PARIWISATA BERKELANJUTAN
}

\author{
I Wayan Mudana \\ Jurusan Pendidikan Sejarah, Fakultas IImu Sosial \\ Universitas Pendidikan Ganesha \\ E-mail: mudana_wayan@yahoo.com
}

\begin{abstract}
Abstrak
Penelitian ini bertujuan untuk mendeskrepsikan tentang bentuk pemberdayaan masyarakat dalam pengembangan pariwisata yang berkelanjutan di Desa Pemuteran. Dalam penelitian ini digunakan pendekatan kualitatif. Pengumpulan data dilakukan dengan observasi, wawancara, dan dokumentasi. Sedangkan analisis data dilakukan dengan triangulasi. Melalaui hal itu dapat dikemukakan bahwa bentuk pemberdayaan yang dikembangkan adalah bentuk pemberdayaan masyarakat lokal. Strategi pemberdayaannya dilakukan secara terpadu baik yang bersifat mikro, mezzo, maupun makro. Kebijakan pemberdayaan masyarakat Desa Pemuteran meliputi pengembangan SDM, pengembangan ekonomi, pengembangan kelembagaan, pengembangan prasara/sarana, dan pengembangan informasi. Pemberdayaan masyarakat Desa Pemuteran seperti itu dapat mendukung pengembangan pariwisata berkelanjutan.
\end{abstract}

Kata Kunci: Pemberdayaan, Pariwisata, Berkelanjutan.

\begin{abstract}
This study aims to describe about the form of the effort of community in develping tourism that is continually in Pemuteran Village. In this study is used qualitatative approach. The collecting data is used by observation, interviewing and document study. While the data analyze carried out with triangele methode. According to this condition can be told, that thae form of effort that developed is the effort of local community. The strategy of this effort is done in intergrated form, with micro, mezzo, or macro. The policy of community's effort in Pemuteran Village, include the development of SDM, economic development, institute development, structure/infrastructure and imformation development. The effort of that Pemuteran Village, should be able to support the tourism development continually.
\end{abstract}

Keywords: The effort, Tourism, Continually 


\section{PENDAHULUAN}

Bali merupakan daerah yang memiliki keaneka ragaman potensi. Hal inilah yang menjadikan daerah Bali sebagai tujuan wisata yang sangat menarik (Covarrubias, 2013). Keberadaan daerah Bali sebagai daerah tujuan wisata dalam perspektif rwa Binneda, hal itu tentu saja dapat berdampak positif dan negatif bagi dinamika sosial, kultural, dan ekonomi masyarakat Bali. Fenomena itu menarik berbagai pihak untuk mengkajinya. Hal ini dapat disimak dari adanya kajian yang dilakukan oleh Atmadja (1993) tentang Pengelolaan Hutan Wisata Kera Sangeh oleh Desa Adat Sangeh, Bali. Kajian ini mengungkapkan kontribusi Desa Adat dan kepercayaan masyarakat dalam melestarian Hutan Sangeh. Mudana (1997) mengkaji tentang Terhimpit di Balik Lipatan Dolar (Kajian Antropologi Terhadap Kehidupan Nelayan pada Kawasan Pemukiman Wisata di Pantai Bali Utara). Kajian ini mengungkapkan telah terjadi keterhimpitan masyarakat lokal di kawasan pemukiman wisata. Pujaastawa, dkk (2005) mengkaji tentang Pariwisata Terpadu Alternatif Model Pengembangan Pariwisata Bali Tengah. Melalui kajian ini terungkap arti penting pengembangan pariwisata terpadu dalam mensinergiskan dan memaksimalkan pemanfaatan dan kebermaknaan pengembangan pariwisata. Hajib (2006) mengkaji tentang Aplikasi Teori Postmodernisme terhadap Aspek Pemberdayaan Masyarakat (Community Empowerment) pada Daerah Tujuan Wisata. Kajian ini mengungkapkan bahwa dengan penerapan teori postmodernisme dalam pemberdayaan masyarakat di bidang pariwisata dapat meningkatkan kualitas aktivitas pariwisata yang berkelanjutan. Anom, dkk. (2010) melalui kajiannya tentang Pariwisata Berkelanjutan dalam Pusaran Krisis Global, mengungkapkan pentingnya pemberdayaan dalam pengembangan pariwisata berkelanjutan. Pitana (2011) mengkaji tentang Pemberdayaan dan Hiperdemokrasi dalam Pembangunan Pariwisata. Dalam kajian ini terungkap arti penting pemberdayaan masyarakat dalam pemanfaatan sumber daya lokal untuk meningkatkan kesejahteraan masyarakat setempat.

Setelah dicermati secara mendalam kajian-kajian tersebut ternyata belum ada yang mengkaji secara khusus mengenai masalah pemberdayaan masyarakat Desa Pemuteran. Namun walaupun demikian harus diakui bahwa kajian - kajian tersebut berkontribusi dalam pengembangan wawasan dan menginspirasi dalam pengembangan kajian pemberdayaan masyarakat Desa Pemuteran dalam kaitannya dengan keberadaan daerah Bali sebagai daerah tujuan wisata. Sehubungan dengan hal itu kajian tentang hal itu penting dilakukan. Petingnya kajian tentang pemberdayaan masyarakat Desa Pemuteran juga terkait dengan keberadaan Desa Pemuteran sebagai salah satu daerah tujuan wisata yang sedang berupaya menata pengembangan pariwisata berkelanjutan, baik secara ekonomi, sosiokultural maupun lingkungan. Pengembangan pariwisata berkelanjutan sangat tergantung pada proses pemberdayaan masyarakat. Adapun permasalahan yang dikaji adalah tentang bagaimana bentuk 
pemberdayaan masyarakat dalam pengembangan pariwisata berkelanjutan di Desa Pemuteran?.

Dalam mengkaji tentang hal tersebut digunakan teori pemberdayaan masyarakat dan teori pembangunan berkelanjutan. Adapun teori pemberdayaan masyarakat yang digunakan diataranya teori pemberdayaan masyarakat berbasis komunitas yang bertumpu pada keberadaan pranata sosial budaya dan psikokultural masyarakat (Bagong Suyanto, 2005; H.Moh Ali Aziz, 2005; H.Nur Syam, 2005). Dalam proses pemberdayaan Jack Rothman sebagaimana dikutip oleh Edi Suharto (2005) mengemukakan tiga model pengembangan masyarakat yaitu: pengembangan masyarakat lokal, perencanaan sosial dan aksi sosial. Harry Hikmat menyatakan ada tiga strategi utama pemberdayaan yaitu: tradisional, aksi langsung, dan transformasi $(2010,19)$. Ketiga strategi tersebut cendrung dilakukan secara terpadu, melalui tiga aras pemberdayaan yaitu aras mikro, mezzo dan makro (Suharto, 2005, 66-67). Berbicara tentang proses pemberdayaan masyarakat tentu juga terkait dengan teori konstruksi sosial interpretative sebagaimana dikemukakan oleh Peter L. Berger dan Thomas Luckman, yang menyatakan bahwa realitas sosial terbentuk secara sosial dan baru memiliki makna setelah dikonstruksi dan dimaknai secara subjektif (1990, 66; Eriyanto, 2008, 204118; Riyanto, 2009). Teori konstruksi sosial sangat penting artinya dalam dinamika kehidupan individu dan masyarakat, karena melalui proses konstruksi sosial aktor merasakan, memikirkan, dan membangun struktur serta kemudian bertindak berdasarkan struktur yang dibangunnya (Ritzer dan Goodman, 2005: 518-523). Di samping teori pemberdayaan kajian ini juga memanfatkan teori pembangunan berkelanjutan terkait dengan pengembangan pariwisata berkelanjutan. Teori pembangunan berkelanjutan kehadirannya terkait dengan adanya ketimpangan pembangunan sebagai konskwensi dari adanya dominan paradigma pembangunan ekonomi yang kapitalistik. Dengan kata lain teori pembangunan berkelanjutan pada dasarnya merupakan suatu alternative untuk mengatasi terjadinya ketimpangan pembangunan. Karena itu teori pembangunan berkelanjutan dipandang sebagai keterpaduan dari paradigma eco-developmentalisme, eco humanism dan eco environmentalism. Sehubungan dengan hal tersebut pembangunan berkelanjutan pada dasarnya menganut tiga prinsip utama, yaitu: (1) kelangsungan ekologi; (2) kelangsungan sosial budaya; dan (3) kelangsungan ekonomi, baik untuk generasi sekarang maupun untuk generasi yang akan dating (Anom, 2010: 5). Konsep pembangunan berkelanjutan semacam itu kemudian diadopsi dalam mengembangkan konsep pembangunan pariwisata berkelanjutan. Ketiga prinsip utama pembangunan berkelanjutan juga harus tampak dalam pembanguan pariwisata berkelanjutan. Dengan demikian pembangunan pariwisata berkelanjutan tidak hanya menekankan adanya keberlanjutan sumber daya alam, dan ekonomi, tetapi juga keberlanjutan sumber daya sosiokultural (Ariana, 2010:179). Dalam 
pembangunan pariwisata berkelanjutan ketiga hal itu bersinergi sehingga tiga elemen pariwisata, yaitu masyarakat setempat, wisatawan, dan sumber daya, dapat berjalan secara simbang dan harmonis serta terjaga kualitasnya (Ariana, 2010: 180). Berpijak dari hal itu diperlukan adanya proses kontruksi sosial dan kontrols sosial. Kontrol sosial dalam perspektif teori kritis dapat diadopsi dari pemikiran Foucault tentang Discipline dan Punish (Foucault, 1997:22-31; Haryatmoko, 2002: 146; Ritzer, 2003: 93-130).

\section{METODE}

Kajian ini menggunakan pendekatan kualitatif. Sehubungan dengan hal itu penentuan informan dilakukan dengan cara purposive snow ball sampling. Pengumpulan data dilakukan dengan teknik observasi, wawancara, dan dokumen. Data yang telah terkumpul dianalisis secara berkelanjutan dengan teknik triangulasi, dan disajikan secara deskreptif kualitatif ( Moleong, 1989; Miles, Matthew B. Dan A. Michael Huberman, 1992).

\section{HASIL DAN PEMBAHASAN}

Desa Pemuteran merupakan selah satu desa yang ada di Kecamatan Gerokgak. Dari segi kewilayahan desa ini memiliki potensi wilayah yang nyegara gunung/ laut dan pegunungan/perbukitan. Kondisi wilayah semacam itu merupakan arena yang potensial bagi pengembangan berbagai usaha produktif baik dibidang pertanian, peternakan dan kenelayanan. Dalam perkembangannya, bahkan sejak tahun 1980-an di desa ini mulai dikembangkan aktivitas pariwisata. Hal itu dimulai dari adanya inisiatif I Gusti Agung Prana pada tahun 1982 memperkenalkan potensi wisata spiritual yang dimiliki Desa Pemuteran kepada berbagai biro perjalanan. Kini Desa Pemuteran berkembang menjadi daerah tujuan wisata yang cukup menjanjikan (Kusumaatmadja, 2000). Hal itu terkait dengan upaya Desa pemuteran mengembangkan pariwisata yang sustainability terhadap lingkungan alam dan sosiokultural. Fenomena berkembangnya Desa Pemuteran sebagai daerah tujuan wisata seperti itu tentu terkait dengan upaya-upaya pemberdayaan masyarakat setempat.

Dalam membedah tentang upaya pemberdayaan masyarakat yang telah dilakukan pada masyarakat Desa Pemuteran diperlukan pemahaman tentang konsep pemberdayaan masyarakat. Konsep pemberdayaan masyarakat meerupakan salah satu konsep utama dalam SosiologiAntropologi Pembangunan. Secara konseptual, pemberdayaan atau pemberkuasaan (empowerment), berasal dari kata "power" (kekuasaan atau keberdayan). Karenanya, ide utama pemberdayaan bersentuhan dengan konsep mengenai kekuasaan. Kekuasaan seringkali dikaitkan dengan kemampuan kita untuk membuat orang lain melakukan apa yang kita inginkan, terlepas dari keinginan dan minat mereka. Pandangan semacam itu merupakan pandangan yang sempit terhadap kekuasaan. Karena kekuasaan senantiasa hadir dalam konteks relasi sosial antar manusia, sehingga kekuasaan dapat berubah-ubah sesuai dengan seting sosialnya. Dengan pemahaman kekuasaan seperti ini, memungkinkan bagi terjadinya proses pemberdayaan. Pemberdayaan memiliki 
kebermaknaan yang sangat berarti terutama pada kelompok renta dan lemah sehingga mereka memiliki kekuatan atau kemampuan dalam memenuhi kebutuhan dasar sehingga mampu menjangkau sumber-sumber produktif yang memungkinkannya meningkatkan pendapatan. Serta memiliki kemampuan dalam berpartisipasi dalam proses pembangunan dan pengambilan keputusan-keputusan dalam mengatasi berbagai masalah yang diadapinya. Secara teoritis dalam pemberdayaan masyarakat ada tiga model yang umum dilakukan, yaitu: (1) model pengembangan masyarakat lokal; (2) model perencanaan sosial; dan (3) model aksi social (Suharto, 2005: 42). Pada masyarakat Desa Pemuteran ke tiga model pemberdayaan tersebut diterapkan, namun yang paling dominan adalah model pemberdayaan masyarakat lokal. Hal ini dapat dilihat dari keterlibatan dan partisipasi masyarakat lokal dalam proses pemberdayaan guna terwujudnya kemandirian, integrasi masyarakat dengan lingkungan sosiokultural dan alam sekitarnya melalui peningkatan kemampuannya. Hal itu dilakukan baik kepada seluruh masyarakat maupun pada beberapa bagian masyarakat melalui kerjasama antara kelembagaan masyarakat Desa Pakraman, Desa Dinas atau kelompok-kelompok fungsional yang ada pada masyarakat dengan pihak ketiga. Berpijak dari hal itu strategi pemberdayaan yang dikembangkan di Desa Pemuteran pada umumnya cendrung menggunakan strategi aras mezzo, namun dalam halhal tertentu juga digunakan strategi mikro dan makro. Pengembangan strategi ini terlihat dari upaya pemberdayaan dilakukan terhadap sekelompok anggota masyarakat yang tergabung dalam satuan organisasi tertentu. Pemberdayaan semacam ini menggunakan kelompok sebagai media intervensi. Pendidikan dan pelatihan, dinamika kelompok umumnya di Desa Pemuteran digunakan sebagai strategi dalam meningkatkan kesadaran, penghetahuan, keterampilan, dan sikapsikap masyarakat agar memiliki kemampuan memecahkan masalah yang dihadapinya.

Fenomena ini dapat disimak dari inisiatif dan keterlibatan aktif masyarakat desa dalam menangggapi pandangan Agung Prana salah seorang pengusaha untuk mengembangkan Desa Pemuteran sebagai desa tujuan wisata. Tanggapan terhadap hal itu dilakukan dalam suatu forum rembug atau sangkepan desa masyarakat Desa Pemuteran. Forum tersebut merupakan forum yang terbuka bagi dialog antar anggota masyarakat dalam menetapkan suatu keputusan. Dalam forum tersebut hadir tokoh-tokoh masyarakat dan anggota masyarakat pada umumnya. Melalui rembug desa semacam itu disepakati untuk mengembangkan desa pemuteran sebagai daerah tujuan wisata. Dalam mengembangkan Desa Pemuteran sebagai desa tujuan wisata, disepakati juga bahwa setiap pengembang fasilitas wisata harus berpegang pada prinsip $60 \%$ lahan digunakan peruntukannya untuk ruang terbuka hijau dan 40\% untuk bangunan fasilitas wisata; setiap pengembang pariwisata di Desa Pemuteran dalam perekrutan tenaga kerja harus mengutamakan tenaga kerja lokal; setiap pengembang pariwisata ikut 
berkontribusi terhadap pembangunan masyarakat desa; dan adanya forum dialog secara berkelanjutan antara tokoh masyarakat Desa Pakraman, Desa Dinas, dengan pengusaha pariwisata setiap akhir bulan.

Partisipasi aktif dari masyarakat Desa Pemuteran dalam pengembangan Desa Pemuteran sebagai daerah tujuan wisata juga dapat dilihat dari inisiatif masyarakat lokal dalam mengembangkan dan memberdayakan pecalang segara. Organisasi ini merupakan hasil kreativitas masyarakat dalam mengoptimalkan keberfungsian dari oraganisasi pecalang yang sudah ada di bawah Desa Pakraman. Hal ini sejalan dengan adanya proses transformasi desa pakraman sebagaimana diungkapkan oleh Pitana (1998). Anggota dari organisasi ini berasal dari wakil-wakil dadia atau kelompok kekerabatan berdasarkan kesatuan cikal bakal/ leluhur. Keberfungsian dari oranisasi ini telah mengantarkan Desa Pemuteran sebagai Desa Model dalam pengembangan pariwisata yang mendukung pelestarian terumbu karang dengan melibatkan partisipasi aktif dari tiga pilar masyarakat yaitu masyarakat sipil, masyarakat ekponomi/pengusaha dan masyarakat politik/ pemerintah.

Dalam proses pemberdayaan masyarakat lokal memanfaatkan berbagai ruang sosial yang dimiliki masyarakat setempat. Ruang ruang sosial tersebut merupakan suatu arena dalam proses kontruksi sosial. Adapun ruang-ruang sosial yang dimanfaatkan sebagai arena sosial dalam mengkonstruksi atau memberdayakan masyarakat diantaranya adalah paruman desa pakraman atau pertemuan desa pakraman, aktivitas upacara keagamaan, dan pertemuanpertemuan organisasi kemasyarakatan yang ada di desa (Karang Taruna, Teruna Teruni, PKK, Pecalang Segara, Yayasan Anak Pemuteran). Di samping itu juga memanfaatkan kelembagaan pendidikan yang ada di Desa Pemuteran. Dengan dekian berbagai potensi kelembagaan merupakan ruang sosial yang strateis bagi proses pengkonsruksiaan/ pemberdayaan masyarakat baik dalam kaitannya dengan pelestarian lingkungan khususnya pelestarian terumbu karang, pengintegrasian sosial/ keharmonisan hubungan antar anggota masyarakat, penguatan kehidupan ekonomi dan pengembangan

pariwisata berkelanjutan. Proses semacam itu tentu saja pelaksaan sangat tergantung dari peran kelembagaan Desa Dinas dan klembagaan Desa Pakraman. Upaya pemberdayaan masyarakat Desa Pemuteran dalam mendukung pengembangan pariwisata yang sustainebelity juga melibatkan pihak ke tiga, seperti Yayasan Karang Lestari yang disponsori oleh I Gst Agung Prana pengusaha pariwisata pemilik Hotel Taman Sari, Yayasan Bio Rock. Yayasan tersebut secara konsisten melakukan pendampingan terhadap masyarakat setempat dalam menjaga kelestarian lingkungan alam pesisir, khususnya dalam melestarikan terumbu karang. Kelestarian terumbu karang di kawasan pesisir pemuteran merupakan daya tarik tersendiri bagi wisatawan. Dengan kata lain pelestarian terumbu karang memiliki keberfungsian dalam mendukung pengembangan pariwisata yang sustainability terhadap lingkungan. Karena pelestarian terumbu 
karang tidak saja memberikan kontribusi terhadap pengembangan pariwisata, peningkatan kehidupan ekonomi tetapi juga berkontribusi bagi kelestarian lingkungan. Upaya kearah pelestarian terumbu karang tidak saja melibatkan masyarakat lokal tetapi juga masyarakat luar. Hal ini dapat disimak dari adanya upaya melibatkan wisatawan untuk ikut berkontribusi dalam pelestarian terumbu karang melalui sponsor pelestarian terumbu karang, sebagaimana yang diwacanakan dalam reklama sponsor a baby coral.

Reklama tersebut merupakaan ide yang sangat kreatif dari Yayasan Bio Rock untuk melestarikan terumbu karang melalui bantuan dari pihak ke tiga. Reklama tersebut menggunakan bahasa Inggris. Reklama sebagai suatu teks tentu memiliki makna denotative dan konotatif, serta sarat dengan berbagai kepentingan dan pertarungan ideologi. Penggunaan bahasa Inggris menyiratkan bahwa masyarakat setempat telah berhasil memberdayakan sebagian dari masyarakatnya dalam berbahasa Inggris, kemampuan berbahasa asing merupakan suatu kemampuan penting bagi masyarakat di daerah tujuan wisata. Karena dengan kemampuan berbahasa asing akan memberikan peluang yang lebih besar untuk ikut terlibat dalam aktivitas di daerah tujuan wisata, atau dengan kata lain masyarakat setempat lebih mudah dalam memanfaatkan berbagai peluang di daerah tujuan wisata.

Namun bila dicermati dari perspektif teori strukturasi Giddens dengan oposisi binerynya (1985, 2003, 2005), reklame tersebut menyiratkan adanya pendekotomian antara dua kelompok masyarakat, yaitu masyrakat tradisional dengan masyarakat modern, masyarakat terbelakang dengan masyarakat maju, masyarakat lokal dengan masyarakat internasional/tamu, masyarakat miskin dengan masyarakat kaya, masyarakat yang tidak berdaya dengan masyrakat berdaya. Hal lain yang cukup menarik adalah adanya ungkapan : Please Contact: Komang at The Bio-Rock Center or Phone Him: 0812461370: $\quad$ http://www.biorock. Ungkapan tersebut tidak saja memiliki makna denotative dalam kaitannya dengan aktivitas komunikasi, tetapi juga merupakan pencitraan sebagai masyarakat yang berdaya, terbuka, maju, modern, dan memiliki kemampuan dalam memanfaatkan masyarakat global dengan isu lingkungannya. Kondisi keberdayaan dari masyarakat Desa Pemuteran juga disiratkan oleh teks dari iklan yang dipajangkan. Dengan meminjam pandangan Roland Barthers bahwa pesan linguistik dari iklam tersebut mengungkapkan harapan kepada masyarakat internasional untuk ikut mendanai keberlanjutan dari proyek pelestarian terumbu karang di Desa Pemuteran. Pemanfaatan teknologi modern seperti internet dan HP dalam perspektif Pilliang menunjukan semakin terbebasnya sekat-sekat dunia sehingga dapat mempersempit jarak dan mempersingkat waktu/mempercepat komunikasi antar kelompok masyarakat di belahan dunia, hal itu menyiratkan dunia telah dilipat (1998; Atmadja, 2006). Bila hal ini dikaitkan dengan pemikiran Foucault yang menyatakan bahwa kekuasaan itu menyebar, maka dapat dikatakan bahwa kuasa dalam iklan tersebut telah mempengaruhi dan mengarahkan pihak lain dalam hal ini 
masyarakat internasional khususnya wisatawan untuk menjadi donator pelestarian terumbu karang. Dalam kuasa masyarakat Desa Pemuteran tentu saja tidak terbebas dari konstruksi berbagai ideologi seperti ideologi, salah satu diantaranya adalah ideologi Tri Hita Karana guna mewujudkan pengembangan pariwisata yang berkeselarasan dengan lingkungan (Salim, 1983; Sukadana, 1983; Sanderson, 1993).

Praktik kuasa dalam media iklan tersebut tentu saja terkait dengan keberhasilan proses pemberdayaan masyarakat yang diwujudkan dalam bentuk kemampuan membuat iklan dan mempermaikan modal natural, modal sosial, modal sumber daya manusia dan modal intelektual yang dimilikinya, sehingga memperkuat kuasa dalam iklan yang dipajangkannya Badaruddin, 2005). Upaya semacam itu tentu merupakan upaya yang sangat positif bagi pelestarian lingkungan dan sekaligus juga berkontribusi bagi pengebangan pariwisata bahari yang berkearifan lingkungan. Upaya semacam ini juga didukung sepenuhnya oleh pemerintah kabupatemn Buleleng, melalui Dinas Kelautan dan Perikanan kabupaten Buleleng, Dinas Pariwisata. Di samping mendapatkan dukungan dari LSM, Pengusaha Pariwisata, Pemerintah Daerah, program pengembangan pariwisata yang sustainebelity terhadap lingkungan juga mendapat dukungan dari lembaga perguruan tinggi, yaitu Universitas Ganesha melalui program P2M Desa Binaan.

Upaya pemberdayaan juga dilakukan oleh Universitas Pemndidikan Ganesha, melalui program desa binaan.
Kegiatan pengabdian pada masyarakat Desa Binaan yang dilakukan meliputi pembinaan pelestarian lingkungan, pengembangan kuliner berbasis potensi lokal, pembinaan guru-guru, dan pembinan karang taruna. Kegiatan tersebut dimaksudkan untuk mengembangkan sumberdaya manusia yang memiliki wawasan yang luas baik yang terkait dengan masalah lingkungan, keorganisasian maupun mengenai masalah kuliner yang dapat mendukung pengembangan pariwisata berkelantan.

Upaya pemberdayaan juga dilakukan melalui ruang sosial Yayasan Anak Pemuteran yang disponsori oleh pemilik Hoten Puri Ganesha, yayasan ini menampung anak-anak pemuteran yang kurang mampu untuk membiayai keberlanjutan pendidikannya. Yayasan ini menyediakan beberapa pasilitas pembelajaran seperti ruang computer, ruang perpustakaan, dan ruang pelatihan tabuh dan tari Bali. Anak-anak dari yayasan ini diberikan ruang untuk menunjukkan kebolehananya menari dan menabuh di haotel-hotel yang ada di Desa Pemuteran. Upaya yang dilakukan yayasan ini memberikan kontribusi yang berarti bagi pelestarian budaya Bali dan pengembangan pariwisata yang sustainebelity terhadap budaya masyarakat setempat.

\section{PENUTUP}

Berpijak dari uraian tersebut di atas maka dapat disimpulkan sebagai berikut: Pemberdayaan yang dikembangkan pada masyarakat Desa Pemuteran merupakan bentuk pemberdayaan masyarakat lokal. Adapun strategi pemberdayaannya dilakukan secara umum dapat dikatakan 
bersifat mezzo, namun dalam hal-hal tertentu juga dilakukan dengan strategi mikro dan makro. Kebijakan pemberdayaan masyarakat Desa Pemuteran meliputi pengembangan SDM, pengembangan ekonomi, pengembangan kelembagaan, pengembangan prasara/sarana, dan pengembangan informasi. Pemberdayaan masyarakat Desa Pemuteran seperti itu mendapat dukungan dari berbagai pihak, baik masyarakat sipil, ekonomi dan politik. Pemberdayaan yang dilakukan pada masyarakat Desa Pemuteran tidak saja mendukung pelestarian alam dan sosiokultural tetapi juga dapat mendukung pengembangan pariwisata berkelanjutan.

Upaya

pemeberdayaan masyarakat Desa Pemuteran seperti itu dapat dijadikan sebagai model pemberdayaan masyarakat di daerah tujuan wisata lainnya. Guna keberlanjutan dari upaya pemberdayaan semacam itu perlu adanya keterlibatan pihak pemerintah daerah dalam mengembangkan suatu standar normative yang dapat dijadikan sebagai acuan dalam mengontrol dinamika pengembangan pariwisata berkelanjutan.

\section{DAFTAR PUSTAKA}

Anom, I Putu, 2010, Pembangunan Pariwisata Berkelanjutan. Dalam Pariwisata Berkelanjutan dalam Pusaran Krisis Global (Penyunting $\mathrm{Bu}$ Ciawi). Denpasar: Udayana University Press.

Ariana, Nyoman, 2010, Pembangunan Pariwisata Bali Yang Berkelanjutan dalam Perspektif Postmodernisme.
Pariwisata Berkelanjutan dalam Pusaran Krisis Global ( Penyunting Bu Ciawi). Denpasar: Udayana University Press.

Atmadja, Nengah Bawa, 1993, Pengelolaan Hutan Wisata Kera Sangeh Oleh Desa Adat Sangeh. Dalam Ekonesia. Vol.1No.1. Mei 1993. Jakarta. Forum Penelitian dan Pengembangan Antropologi Ekologi Program Studi Antropologi-Program

Pascasarjana

Universitas Indonesia.

2006, Bali Pada

Era Globalisasi, Singaraja: IKIP N Singaraja

Azis, H.Moh Ali, 2005, Pendekatan Sosiokultural dalam Pemberdayaan Masyarakat, dalam Pemberdayaan Masyarakat. (editor: Rr.Suhartini, dkk). Yogyakarta: Pustaka Pesantren

Badaruddin, 2005, Modal Sosial (Sosial Capital) dan Pemberdayaan Komunitas Nelayan, dalam 'Isu-isu Kelautan Dari Kemiskinan Hingga Bajak Laut, Yogyakarta: Pustaka Pelajar.

Berger, Peter L dan Thomas Luckman, 1990. Tafsir Sosial atas Kenyataan Risalah Tentang Sosiologi Pengetahuan, Jakarta: LP3ES.

Covarrubias, Migual, 2013, Pulau Bali Temuan Yang Manakjubkan. Denpasar: Udayana University Press.

Eriyanto, 2008, Analisis

Framing.Yogyakarta: LKiS

Foucault, Michel, 1997, Disiplin Tubuh, Bengkel Individu Moder, Yogyakarta: LKiS. 
Gidden, Anthony, 1985, Kapitalisme dan Teori Sosial Modern, Jakarta: Universitas Indonesia.

2003, Masyarakat Post-Tradisional (Penterjemah: Ali Noer Zaman), Yogyakarta: IRCiSod.

$\begin{array}{lc}\text { Konskuensi 2005, } & \begin{array}{c}\text { Konskuensi- } \\ \text { Modernitas, } \\ \text { (Penterjemah: }\end{array} \\ \text { Nurhadi), } \\ \text { Yogyakarta: Kreasi Wacana } \\ \text { Haryatmoko, 2002, } \\ \text { Melahirkan Anti } & \text { Kekuasaan, } \\ \text { Dalam Basis No } & \text { 01-02/2002. } \\ \text { Yogyakarta: PB Basis. } & \end{array}$

Harry, Hikmat, 2010, Strategi Pemberdayaan Masyarakat.

Bandung: Humaniora Utama Press

Kusumaatmadja, Sarwono, 2000, Wisata Bahari Sebagai Andalan Pembangunan Nasional, Makalah , Denpasar: Universitas Udayana.

Miles, Matthew B. Dan A. Michael Huberman, 1992, Analisis Data Kualitatif, Jakarta: Universitas Indonesia.

Moleong, Lexy, 1989, Metodologi Penelitian Kualitatif, Bandung: Remadja Karja.

Mudana, I Wayan,.1997, Terhimpit Dibalik Lipatan Dolar ( Kajian Antropologi Terhadap Kehidupan Nelayan Pada Kawasan Pemukiman Wisata di Pantai Bali Utara), Singaraja: STKIP.

Pitana, I Gde, 1998, Transformasi Desa Adat, Makalah, Singaraja: STIE.

Pitana, I Gde, 2011, Pemberdayaan dan Hiperdemokrasi dalam Pembangunan Pariwisata, dalam Pemberdayaan Hiperdemokrasi dan Pembangunan dalam Pariwisata
Persembahan untuk Prof. Ida Bagus Manuaba, (I Nyoman Darma Putra dan I Gde Pitana Penyunting). Denpasar: Pustaka Larasa.

Pilliang, Yasraf Amir, 1998, Dunia Yang Dilipat Realitas Kebudayaan Menjelang Milenium Ketiga dan Matinya Posmodernisme, Bandung: Mizan.

Pujaastawa,I.B.G. dkk, 2005, Pariwisata Terpadu Alternatif Model Pengembangan Pariwisata Bali Tengah. Denpasar: Universitas Uidayana.

Riyanto, Geger, 2009, Peter Berger Perspektif Metateori Pemikiran. Jakarta: LP3ES.

Ritzer, George, 2003, Teori Sosial Postmodern. Yogyakarta: Juxtapose Research and Publication Study Club bekerjasama dengan Kreasi Wacana.

Ritzer, George, dan Goodman, Douglas J. 2005. Teori Sosiologi Modern. Jakarta: Prenada Media.

Salim, Emil, 1983, Manusia dan Lingkungan Hidup, dalam M. Soerjani dan Bahrin Samad (ed), Manusia dalam Keserasian Lingkungan, Jakarta: Universitas Indonesia.

Sanderson, Stephen K., 1993, Sosiologi Makro, Jakarta: Rajawali.

Suharto,Edi.2005. Membangun Masyarakat Memberdayakan Rakyat. Bandung : Aditama

Sukadana, A Adi, 1983, AntropologiEkologi, Surabaya:Airlangga.

Suyanto, Bagong, 2005. Pemberdayaan Nelayan Tradisional, dalam Modelmodel

Pemberdayaan Masyarakat. (editor: Rr.Suhartini, 
dkk). Yogyakarta: Pustaka Pesantren.

Syam,H.Nur, 2005, Pengelolaan Sumber Daya Perikanan Berbasis Komunitas (PSBK) Suatu Alternatif
Model Pemberdayaan

Masyarakat, dalam Model-model Pemberdayaan Masyarakat. (editor: Rr.Suhartini, dkk). Yogyakarta: Pustaka Pesantren 